\title{
Epigenetics: A New Player in the Regulation of Mammalian Puberty
}

\author{
Paulina A. Rzeczkowska, ${ }^{a, b}$ Huayun Hou ${ }^{c, d}$ Michael D. Wilson ${ }^{c, d}$ \\ Mark R. Palmert ${ }^{\mathrm{a}-\mathrm{c}, \mathrm{e}}$ \\ ${ }^{a}$ Division of Endocrinology, Hospital for Sick Children, ${ }^{b}$ Institute of Medical Science, University of Toronto, \\ 'Genetics and Genome Biology Program, Hospital for Sick Children, dDepartment of Molecular Genetics, and \\ e Departments of Pediatrics and Physiology, University of Toronto, Toronto, Ont., Canada
}

\section{Key Words}

Puberty · Epigenetics · Hypothalamus · DNA methylation · Histone posttranslational modifications - Repression - Gene regulatory networks · Hypothalamic-pituitary-gonadal axis ways affecting pubertal timing. Here we review the findings to date and discuss how epigenetic investigation can further our understanding of this fundamental aspect of human development. (c) 2014 S. Karger AG, Basel

\begin{abstract}
All reproductively competent adults have gone through puberty. While key genes and signaling pathways that lead to the onset of sexual maturation are known, the molecular mechanisms that determine when an individual enters puberty are only beginning to be understood. Both genetic and environmental factors determine the timing of puberty. New advances in understanding how environmentally sensitive, yet highly heritable developmental processes are regulated have come from the field of epigenetics. Of note, studies investigating the epigenetic control of the onset of puberty suggest that epigenetic repression of key inhibitory loci may play a fundamental role in the initiation of puberty. Current technologies that not only read out the DNA sequence, but also determine how the DNA is modified in response to the environment, promise new insight into how puberty is regulated, including the identification and understanding of gene regulatory networks that control the biological path-
\end{abstract}

\section{Introduction}

When gonadotropin-releasing hormone (GnRH) secretion emerges from its childhood quiescence and the hypothalamic-pituitary-gonadal (HPG) axis is reactivated, puberty is initiated, sexual maturation ensues and boys and girls transition into adolescence. Although this is a common experience, the age at the onset of puberty varies greatly among individuals. The age of onset also varies between the sexes; females on average experience the onset of puberty at younger ages than males and are more likely to have idiopathic central precocious puberty while boys are predisposed to idiopathic delayed puberty (referred to as constitutional delay of growth and puberty) [1]. Even within the normal range of age at onset, understanding the causes of variation in the timing of puberty is important because the age of onset is associated

\section{KARGER}

E-Mail karger@karger.com

www.karger.com/nen
(C) 2014 S. Karger AG, Basel

0028-3835/14/0994-0139\$39.50/0
Mark R. Palmert

5110B Burton Wing, Hospital for Sick Children

555 University Avenue

Toronto, ON M5G 1X8 (Canada)

E-Mail mark.palmert@ sickkids.ca 
with later life outcomes. For example, early age at menarche (AAM) is a risk factor for breast cancer [2-4], cardiovascular disease [5], depression [6], eating disorders [7], conduct and behavioral disorders [8], diabetes [9] and increased all-cause mortality [10]. Conversely, late AAM is associated with a decreased risk of ischemic heart disease [11] but an increased risk of osteoporotic fracture $[12,13]$. Boys are also affected by alterations in pubertal timing, with delayed puberty being a cause of bullying, poor self-esteem and psychosocial distress, while early puberty is a risk factor for testicular cancer [8]. Although these associations need to be verified and their biological and/or psychosocial origins clarified, it is clear that pubertal timing impacts health during and after adolescence [14]. It is possible that the identification of pathways that regulate the timing of puberty may lead to the identification of overlapping pathways that play a role in the pathogenesis of some of the outcomes.

Why this variability exists can be explained only partially by genetic background and environmental influences. Recent genome-wide association studies (GWAS) have provided important new knowledge regarding 32 new genetic loci and pathways that regulate the timing of puberty [15-19], but the genetic variants identified, including those associated with the RNA binding protein gene LIN28B, explain less than $7 \%$ of the variation in the timing of menarche [17]. Importantly, for 19 of these 32 loci, the gene closest to the particular locus is a gene known to be directly involved in epigenetic regulation of the genome. Genetic investigation has also identified many other genes that lead to rare disorders of puberty, such as the GnRH gene and its receptor (GNRH1 and GNRHR), the neuropeptide kisspeptin and its receptor [KISS1 and KISS1R (previously referred to as GPR54)], and neurokinin $\mathrm{B}$ and its receptor (TAC3 and TACR3) in hypogonadotropic hypogonadism [for reviews, see 20, 21] and malkorin RING-finger protein 3, MKRN3, in familial precocious puberty [22]. However, sequence variation in these and other disease-causing genes does not appear to be a substantial cause of variation in pubertal timing within the general population. Interestingly, variation in pubertal timing manifests itself even in genetically identical individuals. Although greater in dizygotic twins, variation is present in monozygotic twins [23] and even in inbred rodents sharing largely identical environmental conditions [24, 25] (fig. 1).

Environmental factors also regulate the timing of puberty. Factors such as general health, nutrition, endocrine disrupting chemicals and stress can affect pubertal timing [26-30], and timing can be influenced by environmental

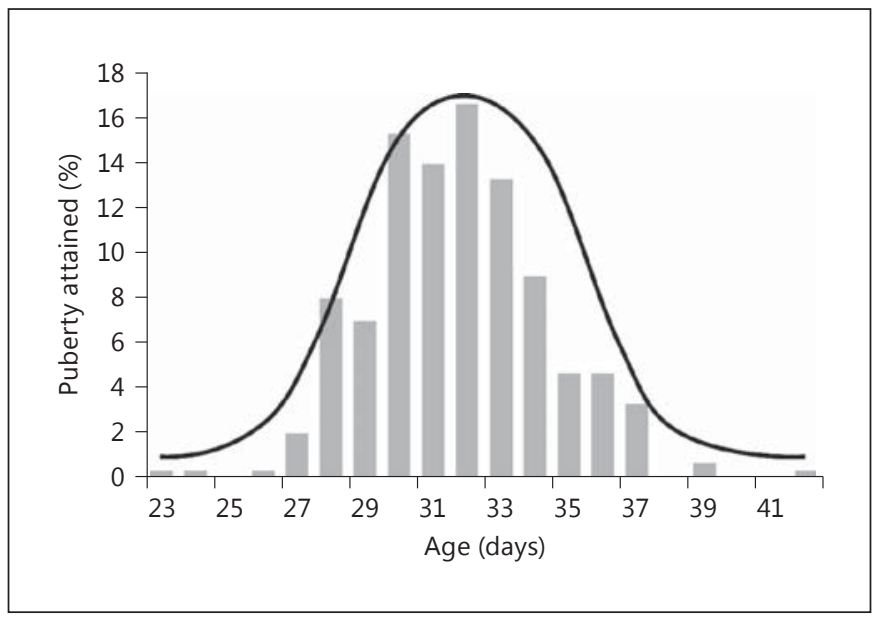

Fig. 1. The timing of puberty approximates a normal distribution. This pattern has been observed in humans, but it is also seen in model systems such as mice, as illustrated here for female mice based on data collected in our laboratory over several years $(\mathrm{n}=$ 298 C57BL/6J mice, mean age of vaginal opening $31.7 \pm 2.6$ postnatal days). Why genetically identical inbred mice display this degree of variability is unclear, but one hypothesis is that it could stem from epigenetic differences. Several macroenvironmental factors have been assessed and do not explain the variability, including litter size, male-to-female ratio in the litter, age of mother and father at mating, and mother's first or second pregnancy. Although extreme differences in litter size can affect phenotypes such as pubertal timing (likely due to the associated over- or undernutrition differences that arise) [123-125], in naturally occurring litter sizes, there is no marked effect on pubertal timing. Proposed epigenetic differences could arise from microenvironmental differences or be stochastic $[126,127]$.

exposures at critical periods, including in utero [31]. It is also known that a complex gene network is involved in coordinating the regulation of pubertal onset and $\mathrm{GnRH}$ release, involving inhibitory, excitatory and permissive inputs that show dynamic regulation that changes over time [32]. The characteristics of transcriptional regulation and phenotypic plasticity suggest that epigenetically mediated gene-by-environment interactions regulate the timing of puberty and may underlie some of the unexplained variability in this process.

\section{What Is Epigenetics and How Might It Affect the Timing of Puberty?}

Epigenetic control systems have emerged as strong determinants of disease and developmental phenotypes. Epigenetics refers to a mitotically heritable layer of tran- 
scriptional control in the absence of changes to the DNA sequence. Common epigenetic mechanisms include differential methylation of 5-methylcytosine $(5-\mathrm{mC})$ in cytosine guanine dinucleotides (CpGs) of DNA and covalent histone posttranslational modifications (HPTMs), such as acetylation and methylation [33]. These modifications affect chromatin structure and gene expression and have been shown to contribute to variation in complex phenotypes including mental disorders, stress response, appetite, metabolism and inflammation [for reviews, see $29,34,35$ ].

Until recently, only a few reports speculated [20, 36, 37] or provided evidence supporting the involvement of epigenetic mechanisms in the regulation of pubertal onset [24, 38-42]. However, exciting recent developments in understanding the mechanisms underlying the reactivation of the HPG axis have pointed to the involvement of an epigenetically mediated control of neuroendocrinerelated gene transcription. Foremost in this area is the recent original research paper by Lomniczi et al. [43] which ushers puberty research more forcefully into the realm of epigenetics. A major development supported by this and other studies is that the activation of neuroendocrine components involved in the initiation of puberty is, at least in part, mediated by an epigenetically mediated lifting of factors that were inhibiting HPG axis neurons during the childhood quiescence.

The search for the genes and gene regulatory networks that are under epigenetic control and involved in determining the timing of puberty is in its infancy. The future involves utilizing innovative, genome-wide scanning approaches to identify genes and pathways that are regulated by epigenetic mechanisms and that play important roles in regulating pubertal onset.

\section{Classic Mammalian Epigenetic Control Systems}

\section{DNA Methylation}

Methylation of cytosine residues (5-mC) of DNA, predominantly in the context of cytosine guanine (CpG) dinucleotides [44], is a key epigenetic mechanism for regulating gene expression. DNA methylation plays a central role in genomic imprinting where either the maternally or paternally inherited allele is methylated and silenced. This results in parent-of-origin effects on gene expression and phenotype [22, 45]. It is interesting in this regard that a recent study in children with precocious puberty identified a paternally expressed imprinted gene (MKRN3) which, when mutated, appears to in-

Epigenetic Control of Pubertal Timing hibit the HPG axis less effectively, resulting in precocious puberty [22].

5 -mC plays important roles outside of imprinting and is typically associated with lower levels of expression [46], with some noted exceptions [47]. 5-mC regulates gene expression through methylation at promoters but also at intragenic and intergenic sites, with DNA methylation of intragenic sites being a regulator of tissue and even cellspecific gene expression [48]. The degree of DNA methylation is controlled by the activity of DNA methyltransferases but can also be affected by other mechanisms such as transcription factor binding at or near $\mathrm{CpG}$ sites, which can lead to loss of methylation [49]. Transcription factor binding has been shown to be a necessary and sufficient means of generating low-methylated regions and of effecting cell-type-specific gene regulation [50].

To understand the interplay between DNA methylation and genetic variation, Gutierrez-Arcelus et al. [51] obtained gene expression and $\mathrm{CpG}$ methylation data from 3 cell types (fibroblasts, $\mathrm{T}$ cells and lymphoblastoid cells) from over 200 healthy newborns. This study showed that variability in interindividual gene expression is associated with differential methylation specifically in the genomic regions that they found to show differential methylation between the 3 cell types. This result highlights the importance of DNA methylation at specific regions during development and suggests that epigenetic changes at these select genomic regions are more likely to be functionally relevant. Importantly, this variability in gene expression was also linked to variation in DNA sequence. Overall this study gives new insight into the cross-talk between genetics and epigenetics, which is certainly reflected in recent mechanistic studies of pubertal development [43].

The pattern of $5-\mathrm{mC}$ in DNA is dictated by the relative activity of enzymes acting to add, remove or maintain this epigenetic mark. The enzymes responsible for maintaining DNA methylation patterns during replication and catalyzing de novo DNA methylation are the DNA methyltransferases DNMT1 and DNMT3a and b, respectively [52]. DNA demethylation, on the other hand, can occur passively or actively. The passive loss of 5-mC occurs during DNA replication [53]. Active demethylation occurs through the oxidation of 5-mC to 5-hydroxymethyl cytosine $(5-\mathrm{hmC})$ by the ten-eleven translocating enzymes, which is followed by full demethylation by thymine DNA glycosylase-mediated base excision and the regeneration of unmodified cytosines through DNA repair pathways [53]. It has recently been shown that $5-\mathrm{hmC}$ is also enriched in active genes in neuronal tissues and can be 
bound by the Rett syndrome protein methyl CpG binding protein 2 [54], thus providing a clear link between $5-\mathrm{hmC}$ and chromatin regulation. Relevant for research on pubertal timing, a survey of $5-\mathrm{hmC}$ in the mouse brain revealed high levels of $5-\mathrm{hmC}$ in the hypothalamus [55].

\section{Histone Modifications}

HPTMs, such as acetylation (Ac) and methylation (me), regulate gene expression during development and in response to the environment. HPTMs are a cornerstone of epigenetic regulation. Changes in HPTMs occur in response to gene regulatory events such as the binding of transcription factors to DNA and can be stably inherited through mitosis. The precise genomic location of HPTMs in a wide variety of cell lines and primary tissues from multiple species, and developmental stages are becoming increasingly available owing to the use of chromatin immunoprecipitation followed by high-throughput DNA sequencing (ChIP-Seq). In particular, the Encyclopedia of DNA Elements Consortium ENCODE [56] and the NIH Roadmap Reference Epigenome Mapping Consortium [57] have used ChIP-Seq to generate genome-wide data for several HPTMs in hundreds of different samples. Analysis of these data has shown that a subset of these HPTMs is able to annotate the entire genome into discrete chromatin states of relatively active or silenced gene expression $[58,59]$. Although dozens of HPTMs have been mapped to the genome of several cell types, the HPTMs histone $\mathrm{H} 3$ lysine residue 4 monomethylated chromatin mark (H3K4me1), H3K4me2 and H3K27Ac (active enhancers), H3K4me3 (transcription start sites), H3K36me3 (actively transcribed gene bodies) and $\mathrm{H} 3 \mathrm{~K} 27 \mathrm{me} 3$ (repressed gene regions/or poised promoters and enhancers) are a particularly informative means of annotating the genome into biologically meaningful categories (fig. 2).

HPTMs can function to physically aid or obstruct the access of transcriptional machinery to transcriptional start sites, gene regulatory regions and gene bodies [60]. Presence of histone acetylation, which is added by histone acetyltransferases [61], leads to less compact chromatin and easier access to transcription start sites. Conversely, deacetylation by histone deacetylases causes chromatin to be more tightly coiled because positively charged DNA winds around the negatively charged histones more fully in the absence of neutralizing acetyl groups $[62,63]$, leading to decreased gene expression.

Methylation of histones can also affect gene transcription. The inhibitory histone $\mathrm{H} 3$ lysine residue 27 trimethylated chromatin mark (H3K27me3) is deposited by the Polycomb group repressive complex 2 (PRC2), a dynamic complex of chromatin-associated proteins that mediate epigenetic silencing of transcription through chromatin compaction [64]. When H3K27me3 co-occurs with the activating HPTM histone $\mathrm{H} 3$ lysine residue 4 trimethylated chromatin mark ( $\mathrm{H} 3 \mathrm{~K} 4 \mathrm{me} 3)$ that resides at transcription start sites, the region is often described as bivalent or developmentally poised [65] (fig. 2). RNA polymerase II is bound in this region, but its activity is paused until H3K27me3 inhibition is lifted. The mechanisms that activate these $\mathrm{H} 3 \mathrm{~K} 27 \mathrm{me} 3$ silenced or poised promoters/enhancers have been implicated in puberty regulation [43] making the regulation of the PRC2 complex during HPG axis development of great interest. In related work, histone demethylation via lysine-specific demethylase (LSD1) has also been linked to alterations in pubertal timing in rodents [42].

Histone modifications can have long-term effects on gene regulation and can serve as a 'metabolic memory' that can have important consequences during disease progression. For example, vascular smooth muscle cells obtained from diabetic mice retain their diabetic phenotype after several weeks in culture [66]. This epigenetic phenomenon has been linked to a loss of the repressive histone $\mathrm{H}_{3}$ lysine residue 9 trimethylated chromatin mark (H3K9me3) at inflammatory genes, which in turn results in hypersensitivity to inflammatory stimuli. Further supporting this idea is a recent study in macrophages that illustrates the concept of activating 'epigenetic scars' which are comprised of HPTMs (monomethylation of the lysine 4 on histone $\mathrm{H}_{3}$; $\mathrm{H} 3 \mathrm{~K} 4 \mathrm{me} 1)$ that occur due to an inflammatory event and remain associated at specific DNA loci long after inflammatory stimuli have been washed away [67]. These 'epigenetic scars' are distinct from poised enhancers marked by $\mathrm{H} 3 \mathrm{~K} 27 \mathrm{me} 3 / \mathrm{H} 3 \mathrm{~K} 4 \mathrm{me} 1$ and result in enhanced activation of specific genes upon restimulation. The possibility of repressive or activating 'epigenetic scars' occurring in early development that later manifest themselves in differences in pubertal timing due to additional environmental stimuli is an intriguing epigenetic mechanism that could generate variability in pubertal timing.

In summary, different activity of the various components of the epigenetic machinery leads to differing patterns of DNA methylation, histone acetylation and histone methylation. These differences provide a powerful mechanism to regulate gene expression that can vary from individual to individual, over time, and across development. 


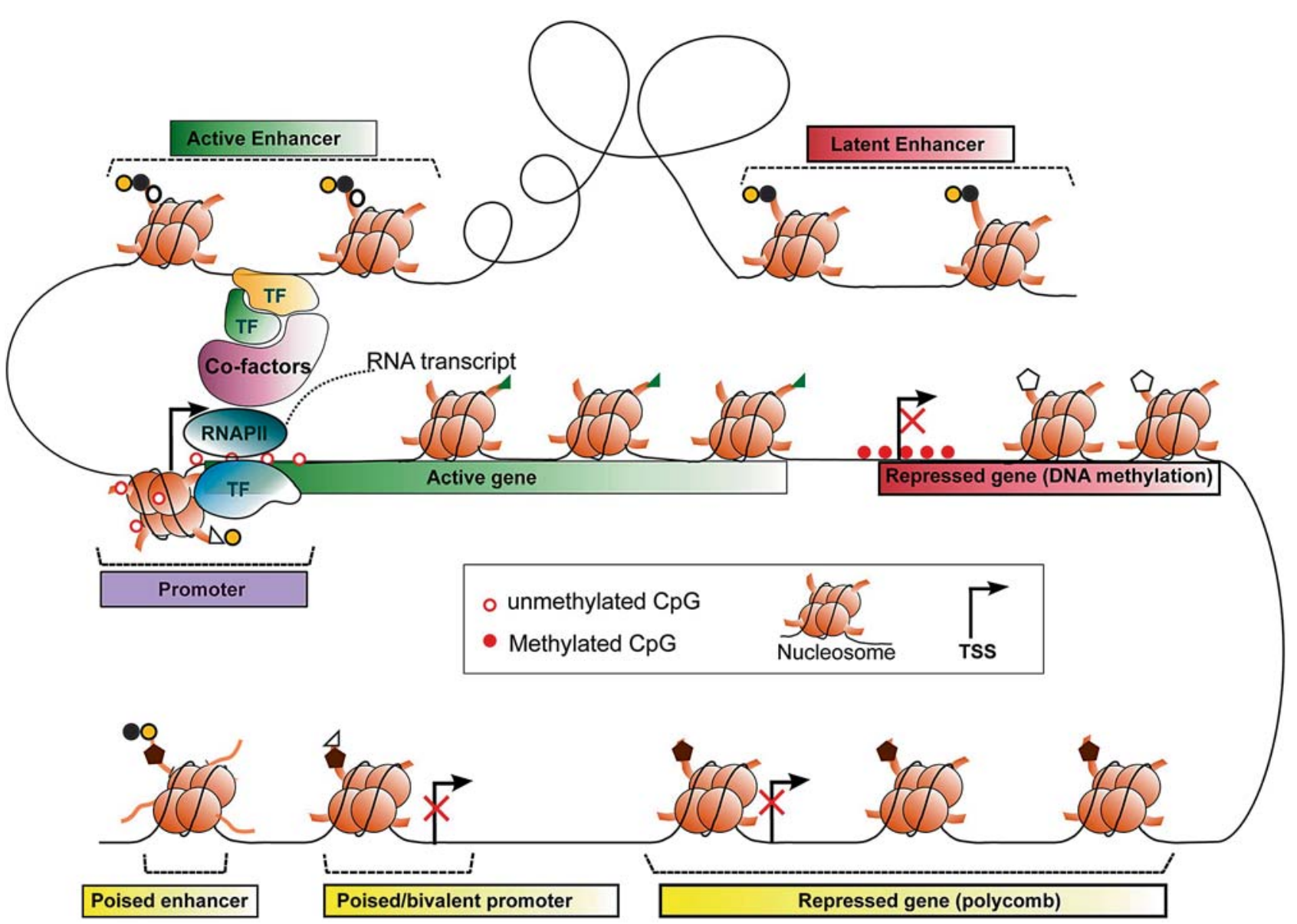

Abbreviation

Full name of HPTM

Functional associations

$\begin{array}{llll}\text { H3K4me1 } & \text { Histone H3 lysine } 4 \text { monomethylation } & \text { Active/latent/poised enhancers } \\ \text { H3K4me2 } & \text { Histone H3 lysine } 4 \text { dimethylation } & \text { Active/latent/poised enhancers/promoters } \\ \text { H3K4me3 } & \text { Histone H3 lysine } 4 \text { trimethylation } & \text { Active promoters } \\ \text { H3K27Ac } & \text { Histone H3 lysine } 27 \text { acetylation } & \text { Actively transcribed genes } \\ \text { H3K36me3 } & \text { Histone H3 lysine } 36 \text { trimethylation } & \text { Permanent repression at heterochromatin } \\ \text { H3K9me3 } & \text { Histone H3 lysine } 27 \text { trimethylation } & \text { Temporary repression at latent/poised enhancers/ } \\ & \text { Histone H3 lysine } 9 \text { trimethylation } & \text { Permanent repression at heterochromatin }\end{array}$

Fig. 2. Overview of commonly studied epigenetic modifications to histone proteins and DNA, and their effects on gene expression. The black line represents DNA. TSS = Transcription start site; TF = transcription factor; RNAPII $=$ RNA polymerase 2 . 


\section{Evidence that DNA Methylation and Histone Modifications Regulate Pubertal Timing}

Various pharmacological agents have the ability to perturb epigenetic marks on a global scale, and the prepubertal period is one during which DNA is highly susceptible to epigenetic changes [68]. These factors led three independent research groups to attempt to modify the epigenome in prepubertal rodents to determine if alterations of epigenetic profiles would lead to changes in pubertal timing. The results from all three groups were consistent with a mechanism that requires the lifting of inhibitory inputs for puberty to occur.

\section{Pharmacological Perturbation of the Epigenome}

Using 5-azacytidine (AZA), a powerful inhibitor of DNA methyltransferases (DNMTs) and hence DNA methylation, Lomniczi et al. [43] provide strong evidence that the timing of puberty is under an inhibitory control. In their work, AZA was administered to prepubertal female rats. Compared with controls, rats that received AZA showed a delay in puberty and reproductive maturation. Vaginal opening, an estrogen-dependent marker of the onset of puberty in rodents, was delayed, with control rats reaching this milestone at $31.33 \pm 0.21$ days and rats treated with AZA reaching vaginal opening much later at $36.67 \pm 0.67$ days $(\mathrm{p}<0.001$; fig. 3a). Ovarian morphology also showed evidence of delayed maturation with ovaries of AZA-treated rats at 28 days being smaller and having fewer mature antral follicles than ovaries of control rats (fig. 3b), and ovaries of 44-day-old AZAtreated rats lacking corpora lutea. Finally, the AZA-treated rats also showed disrupted estrous cyclicity compared to controls. Since AZA inhibits methylation, it will in general lead to increased gene expression; since this increased gene expression leads to delayed puberty, the findings argue for an effect on genes that inhibit HPG axis activation.

In parallel to the work by Lomniczi et al. [43], we asked whether administering the histone deacetylase inhibitor suberoylanilide hydroxamic acid (SAHA) to female mice could alter pubertal timing. In unpublished experiments, Rzeczkowska et al. [24] corroborate the findings of Lomniczi et al. [43] as SAHA treatment delayed the onset of puberty. This was evidenced by significantly lighter ovarian weights than controls ( $1.6 \pm 0.1$ vs. $2.0 \pm 0.1 \mathrm{mg}, \mathrm{p}<$ 0.01 ) on day 32 (fig. $3 \mathrm{~d}$ ), lighter uterine weights (11.4 \pm 1.7 vs. $17.1 \pm 3.0 \mathrm{mg}, \mathrm{p}<0.01)$ on day 32 and a trend towards delayed age at vaginal opening (fig. $3 \mathrm{c}$ ). As a histone deacetylase inhibitor, SAHA ultimately leads to increased histone acetylation [69-72] allowing gene tran- scription to proceed. Increased gene expression is enhanced further because SAHA can also cause decreased DNA methylation [73-75], like AZA. That increased gene expression leads to delayed puberty, once again implies that genes that inhibit pubertal onset were those most affected by the administration of an agent that alters the epigenome.

In complementary studies, L-methionine (L-MET) was administered to another group of prepubertal female mice. L-MET increases the supply of available methyl groups for DNMTs to use for cytosine methylation because L-MET is converted to the methyl donor S-adenosyl methionine [76]. Therefore, we hypothesized that L-MET administration would decrease gene expression and exert an opposite effect on pubertal timing compared with SAHA. Indeed, administering L-MET resulted in earlier puberty, as evidenced by vaginal opening occurring significantly earlier in treated mice than in controls (30.5 \pm 2.2 vs. $31.6 \pm 2.2$ days, $\mathrm{p}<0.05$; fig. $3 \mathrm{c}$ ) accompanied by a trend towards heavier uterine weights than controls ( 22.2 \pm 3.6 vs. $17.1 \pm 3.0 \mathrm{mg}$ ) [24].

\section{Nonpharmacological Alteration of the Epigenome}

Finally, a third research group determined that a rise in histone methylation early in life is associated with earlier pubertal timing [42]. Their unpublished studies show that the epigenome was altered by decreasing histone lysine demethylase levels through the use of lysine-specific demethylase heterozygous knockout mice (LSD1 +/-). The authors found increased histone methylation early in life associated with earlier age at vaginal opening. The data imply that increased expression of an LSD1 target led to the earlier puberty (since the knockout of Lsd1 should lead to a rise in histone methylation that would be expected to lead to increased transcription). Although the downstream targets of LSD1 were not identified in this study, Lomniczi et al. [43] and others [42] have shown that Kiss1, the gene encoding kisspeptin, an established puberty-activating neuropeptide, is an LSD1 target. It is therefore feasible that lower levels of $L s d 1$ led to increased Kiss 1 levels and earlier puberty. An alternative explanation is that the demethylase was acting to remove methylation at a mark such as $\mathrm{H} 3 \mathrm{~K} 9$, a histone methylation mark that silences transcription of its target genes. In this case, $\mathrm{H} 3 \mathrm{~K} 9 \mathrm{me} 3$ could be localized to puberty repressor genes, and silencing of the repressor genes could have led to the earlier onset of puberty.

The perturbations employed in these studies, whether they were pharmacological or nonpharmacological, were administered in a systemic fashion via intraperitoneal in- 

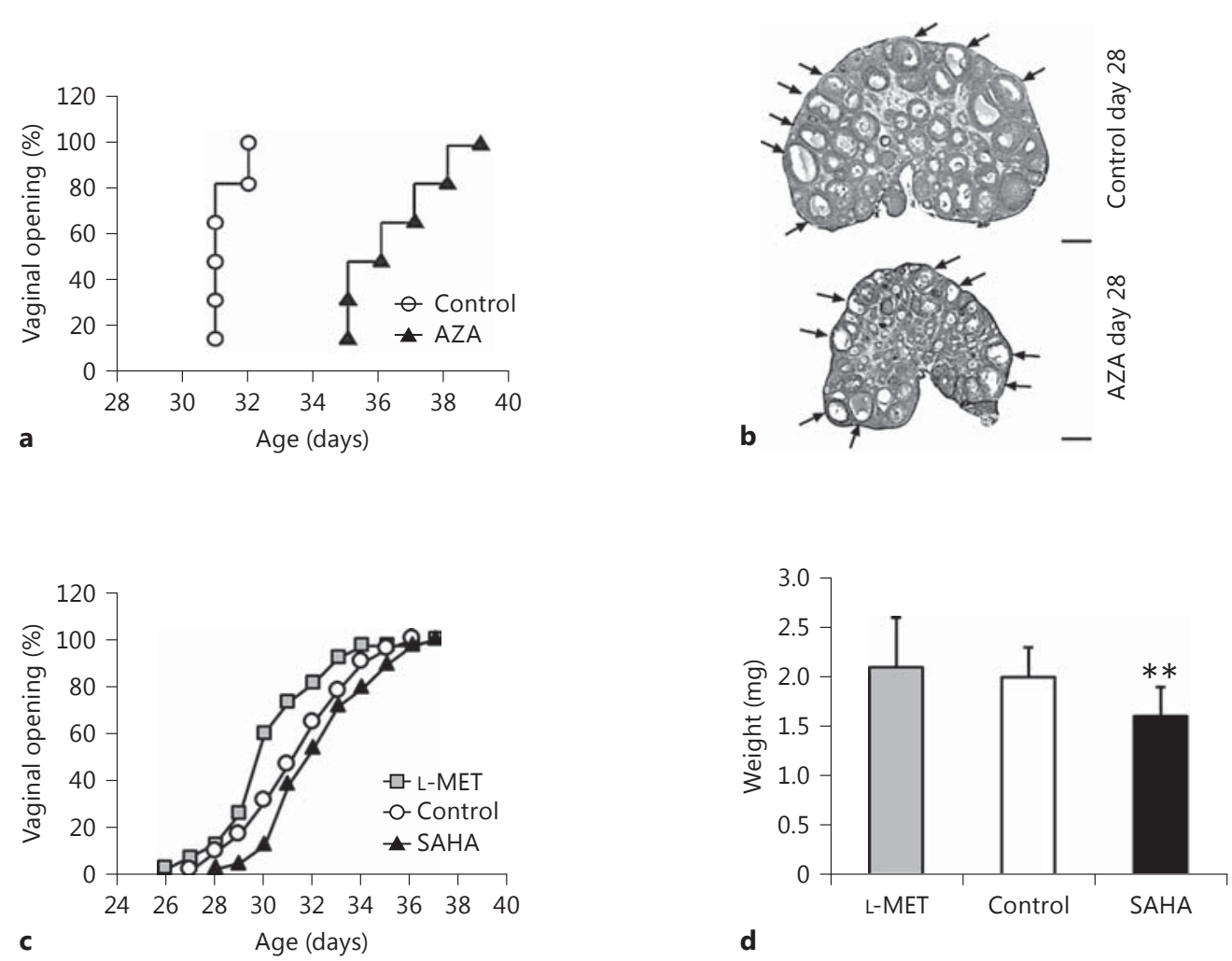

Fig. 3. In vivo perturbation of DNA methylation and histone acetylation results in changes to timing of onset of puberty in female rodents. Mean \pm SEM throughout. SAHA = Suberoylanilide hydroxamic acid; L-MET = L-methionine. Panels $\mathbf{a}$ and $\mathbf{b}$ reprinted by permission from Macmillan Publishers Ltd., copyright 2013. a, b Lomniczi et al. [43] have demonstrated that rats intraperitoneally injected daily with AZA from postnatal day 22 onward have a markedly delayed vaginal opening (a; mean age $36.67 \pm 0.67$ days, $\mathrm{n}=6)$ compared to controls $(31.33 \pm 0.21$ days, $\mathrm{n}=6 ; \mathrm{p}>0.001)$ as well as delayed ovarian maturation (b), indicated in day 28 ovarian micrographs from AZA-treated versus control rats by morphologically smaller ovaries and presence of fewer antral follicles (arrows), hallmarks of female rodent pubertal onset. The evidence from this group indicating that the changes in epigenetic marks

jection [43], orally through drinking water [24] or globally as a gene knockout [42]. As such, these modes of administration do not allow for identification of the specific tissue(s) in which causative alterations occurred. However, Lomniczi et al. [43] did perform a series of experiments that allowed them to localize the effects of AZA administration on pubertal timing to the hypothalamus. In addition, these authors observed no negative effects of AZA treatment within other hormonal systems, such as prolactin and corticosterone, that might have affected the can affect the timing of puberty is supported by complementary studies using L-MET and SAHA. Scale bar $=100 \mu \mathrm{m}$. c Mice treated with L-MET via drinking water from day 21 display earlier puberty (vaginal opening at $30.5 \pm 2.2$ days, $n=26$, compared to controls $31.6 \pm 2.2$ days, $n=51 ; p<0.05$ ), and those treated with SAHA dissolved in the vehicle hydroxypropyl- $\beta$-cyclodextrin in the drinking water display a trend towards delayed puberty $(32.5 \pm 2.1$ days, $n=37$ ). Control mice administered water only or water and vehicle were pooled, having shown no significant differences. d 32-day-old mice treated with SAHA have smaller ovaries (1.6 \pm $0.1 \mathrm{mg}, \mathrm{n}=15$, vs. $2.0 \pm 0.1 \mathrm{mg}, \mathrm{n}=20)$ than controls $(\mathrm{p}<0.01)$, consistent with later pubertal development, whereas mice treated with L-MET have a trend toward larger ovaries at the same age $(\mathrm{n}=22)[24]$.

timing of puberty. Nonetheless, effects elsewhere cannot be ruled out. Further studies designed to identify responsible tissues and particular $\mathrm{CpG}$ and other marks that modulate the HPG axis and the timing of puberty will be an important area of future studies.

In total, the studies reported to date do provide consistent, though somewhat indirect evidence that altering the epigenome can alter pubertal timing (table 1). Although it is likely that epigenetic factors regulate nearly all developmental processes, the aforementioned studies 
Table 1. Summary of effects of globally perturbing epigenome on timing of puberty in female rodents

\begin{tabular}{|c|c|c|c|c|}
\hline \multirow{4}{*}{$\begin{array}{l}\text { Perturbation } \\
\text { Mechanism of action } \\
\text { Consequence to transcription } \\
\text { Result on pubertal timing }\end{array}$} & \multicolumn{4}{|c|}{ Epigenetic mechanisms } \\
\hline & $\mathrm{AZA}$ & SAHA & L-MET & $+/-$ LSD1 \\
\hline & $\downarrow$ DNA methylation & $\uparrow$ Histone acetylation & $\uparrow$ DNA methylation & $\uparrow$ Histone methylation \\
\hline & \multicolumn{2}{|c|}{ Delay puberty } & \multicolumn{2}{|c|}{ Advance puberty } \\
\hline
\end{tabular}

Interpretation of mechanism

Initiation of puberty requires repression of repressors

AZA data derive from Lomniczi et al. [43], SAHA and L-MET data derive from Rzeczkowska et al. [24], and +/- LSD1 data derive from Gill et al. [42].

together provide strong evidence that epigenetic factors are key players in the regulation of the onset of puberty. This concept is consistent with other work indicating that epigenetic mechanisms regulate the HPG axis at other stages of development [for a review, see 77]. Examples include regulation of $\mathrm{GnRH}$ gene expression in cultured neurons $[41,78,79]$, of the estrogen- $\alpha$ receptor gene in the hypothalamus [80] and of Kiss1 in the rodent brain during sexual differentiation [81] and during estrogen positive and negative feedback [82]. It is evident that further investigation of epigenetic mechanisms within the HPG axis, across tissues and developmental states, will be an important step towards further understanding the complexity of pubertal regulation and the coordinated layers of its control within gene regulatory networks [32, $83,84]$.

\section{Assay of Genome-Wide DNA Methylation}

Leveraging array-based platforms, Lomniczi et al. [43] performed a genome-wide scan of DNA methylation differences in rat hypothalamic samples across the pubertal transition. Data for all RefSeq promoters and more than 15,000 annotated $\mathrm{CpG}$ islands were obtained, aiding in the discovery of previously unknown regulators of pubertal timing. The authors found enrichment in a cluster of chromatin/histone modification genes that are members of or interact with Polycomb group gene silencing complexes. The assay detected a rise in promoter methylation relative to $\mathrm{CpG}$ island methylation in many of these genes with the advent of puberty. This rise in methylation supports the probable mechanism of decreasing expression of repressive genes, facilitating the onset of puberty by lifting inhibitory signals.

Assessing the functional significance of particular genes discovered by the genome-wide assay suggests that regulation of the onset of puberty may also involve epigenetic control of epigenetic machinery. For example, a component of the PRC2, the embryonic ectoderm development gene (Eed), was found to be silenced in the hypothalamus by DNA methylation at the initiation of puberty [43]. Prior to the initiation of puberty, Eed was bound to the Kiss 1 promoter, mediating the prepubertal repression of Kiss 1 expression. Kiss 1 repression was lifted at puberty by the epigenetic silencing of Eed, leading to diminished association of EED with the Kiss 1 promoter and increase in Kiss 1 mRNA expression. This was accompanied by a rise in activating histone marks H3K4me3 and $\mathrm{H} 3 \mathrm{~K} 9,14 \mathrm{Ac}$ at the Kiss 1 promoter at the initiation of puberty, and a drop in the repressive histone mark H3K27me3 after the initiation of puberty, resulting in changes to chromatin structure that facilitate transcription. How this system regulates the timing of puberty in coordination with other inputs is not yet known. For example, kisspeptin is found in neurons in the arcuate nucleus of the hypothalamus that also produce neurokinin $\mathrm{B}$ and dynorphin, termed KNDy neurons [85]. These other peptides also regulate GnRH secretion [86], and it is feasible that the genes encoding these neuropeptides are also epigenetically regulated during pubertal onset. How epigenetic mechanisms regulate the function of the network of inputs that control GnRH secretion will likely be an important topic of research for many years [84].

Further evidence supporting a complex system derives from treatment of the rats with the DNMT inhibitor AZA. AZA decreased methylation at the Eed promoter and prevented the pubertal fall in its expression. Increased Eed expression was accompanied by continued low-level Kiss 1 expression. Conversely, when Eed was overexpressed, Kiss 1 expression dropped, GnRH response was blunted, and pubertal developmental was delayed. The studies by Lomniczi et al. [43] and others [24, 42, 87] need to be replicated and expanded, but they clearly represent a step forward in our understanding of the regulation of puberty and provide an important construct for future studies. 


\section{Emerging Epigenetic Mechanisms and How They Might Affect the Timing of Puberty}

\section{Epigenetic Regulation by Noncoding RNAs}

Although not as well studied as DNA methylation or HPTMs, evidence for roles of noncoding RNAs, which act to reduce gene expression, in epigenetic regulation is continuing to emerge $[88,89]$. Early examples of long noncoding RNAs (lncRNAs) include genes such as Xist and H19, which are involved in $\mathrm{X}$ inactivation and imprinting, respectively. More recently, loss of function studies in mouse embryonic stem cells show that lncRNAs can affect gene expression of distant genes and are involved in controlling pluripotency and cellular differentiation [90, 91], including the differentiation of neurons from human embryonic stem cells. Such lncRNAs may serve as scaffolds or decoy binding sites for epigenetic machinery and transcription factors $[88,89]$.

As noted previously, GWAS have identified 32 loci that affect the AAM in humans. The responsible gene at one of those loci, LIN28B, encodes a cytoplasmic RNA binding protein that acts to inhibit production of noncoding RNAs, termed microRNAs, and hence acts as a repressor of repressors. Overexpression of homologues of LIN28B, Lin28 in Caenorhabditis elegans [92] and Lin28a in female mice [93], leads to delayed larval development and delayed puberty, respectively. Additionally, expression of various $\operatorname{Lin} 28$ family members in the hypothalamus of rodents decreases prior to the onset of puberty [94, 95]. It is also relevant to note that lncRNA_N2, which is needed for neuronal specification, contains microRNA LET7A within its intron [90]. Together, these studies indicate that regulation by microRNAs is a key epigenetic mechanism involved in regulating pubertal timing.

\section{Epigenetic Regulation through Transcription Factor Binding}

Transcription factors can bind to DNA individually or in combination, and different combinations present in different tissues at different developmental stages are important determinants of spatial and temporal gene expression [96-98]. Transcription factor binding affects gene expression by altering chromatin structure and DNA accessibility.

Transcription factors have long been known to play important roles in the HPG axis $[21,99,100]$. For example, mutations in PROP1, HESX1 and LHX3 all affect pituitary development whereas mutations in NR5A 1 lead to defects in the ovaries, testes and adrenal glands. In addition, 15 of the 32 genes associated with AAM are tran-

Epigenetic Control of Pubertal Timing scription factors. Although mechanisms have not yet been defined, these GWAS data underscore the role that transcription factors play in modulating the timing of puberty. The transcription factor IRF2BPL [interferon regulatory factor 2 binding protein-like, which has been referred to as EAP1 (enhanced at puberty 1)] is another transcription factor implicated in pubertal control. Expressed in the rodent hypothalamus, EAP1 has been linked to delayed puberty in animal models [101].

Thus, it is evident that transcription factors play an important role in the epigenetic control of HPG axis development and in the control of the timing of puberty. Since many of the key transcription factors and their targets are only just beginning to be uncovered, it is likely that these transcription factors will emerge as even more important regulators of the timing of puberty in the future.

\section{Long-Range Gene Regulation by Three-Dimensional}

Chromatin Configurations

The organization of chromatin can result in longrange interactions, which can bring distal tissue-specific enhancers to promoters (fig. 2) [102]. For example, mutations affecting the sex-determining SOX9 gene occur from 50 to $1,000 \mathrm{~kb}$ upstream of the gene [103]. At the center of these long-range interactions are looping factors: the transcription factor CTCF and the ring-shaped cohesin complex, both of which play critical roles in controlling the epigenome [for a review, see 104]. The formation of long-range interactions directly involves a combination of several epigenetic mechanisms - transcription factor binding, histone modifications and DNA methylation - and understanding these types of complex interactions may well be part of understanding genome control during puberty more fully.

Characterizing long-range DNA interactions is a major post-GWAS problem where the fundamental challenge is often linking disease-associated loci to the responsible gene. One of the most comprehensive studies to date that mapped long-range DNA interactions across the mouse genome reported that at least $50 \%$ of genes undergoing transcription are involved in at least one longrange interaction [105]. The challenge of identifying long-range interactions presents itself in AAM GWAS results where 20 of 32 loci identified are located at least 10 $\mathrm{kb}$ from the nearest gene [106].

The disruption of long-range epigenetic interactions has been linked to pubertal timing. In what may be an initial example, the genetic study of a girl with precocious puberty and severe mental retardation identified an 8.9$\mathrm{Mb}$ duplication whose distal breakpoint was $600 \mathrm{~kb}$ away 
from the kisspeptin receptor (KISS1R) [107]. Given the prevalent role of KISS1R in puberty, a plausible explanation is that the duplication had disrupted a long distance chromatin interaction(s) that interrupted the spatial temporal expression of KISS1R during puberty.

The tissue-specific nature of 3-dimensional interactions and their regulation will likely represent a major challenge to understanding the factors that regulate the timing of puberty. However, recent developments creating and analyzing genome-wide maps of open chromatin generated by the DNA cleavage enzyme deoxyribonuclease I (DNAse I) have identified open chromatin in a wide array of tissues and cell lines and allowed predictions to be made about which of these open chromatin regions are likely to interact in 3 dimensions [108]. Relevant to puberty research, similar techniques were used to show that of all the GWAS variants reported for any disease in the NCBI database, the AAM-associated single-nucleotide polymorphisms show the highest enrichment of fetal specific regulatory elements (open chromatin) [109]. This exciting observation strongly suggests that important aspects of the epigenomic landscape of pubertal timing are established early in development.

\section{Future Opportunities and Challenges}

Importance of Constructing Gene Regulatory Networks Linking puberty-associated genes into pathways is an important area of future research and one that has been championed by Ojeda and his group [32, 83, 84]. Meeting this need will be an important step towards further understanding the complexity of the regulation of the timing of puberty and investigating the coordinated layers of its control within gene regulatory networks. Rare human mutations, GWAS and animal models have clearly shown that puberty is driven by a complex network of genes and by hierarchical levels of stimulatory and inhibitory components $[32,83,84]$.

Finding genetic interactions can give insight into how genes work within networks to carry out complex cellular processes [110]. One way to identify these interactions is to use radiation hybrid panels that measure attraction or repulsion of gene pairing higher than by chance alone. More than 7 million genetic interactions have been characterized using human, mouse, rat and dog radiation hybrid panels [111]. Applying radiation hybrid data to the genes and loci involved in regulating pubertal timing shows that many of the genes are found together in genetic networks (fig. 4). This information contrasts with the observation that the most significant GWAS identified single-nucleotide polymorphisms for AAM [106] did not occur near known hypogonadotropic hypogonadism and Kallmann syndrome genes [20] and reiterates that genetic interactions are not dependent on proximity. There are, of course, limitations to the radiation hybrid approach to finding genetic interactions in multicellular organisms that utilize hormones to signal across tissues. For example, the receptor-ligand pairs in this analysis (e.g. KISS1/KISS1R, GNRH1/GNRHR) do not show genetic interactions. Nonetheless, the novel genetic interactions identified create new testable hypotheses.

Experimental Strategies for Identifying Components of Gene Regulatory Networks

In addition to whole-genome DNA methylation assays, examining whole-genome gene expression patterns using RNA sequencing is another way to identify epigenetically controlled genes for the creation of gene regulatory networks. RNA sequencing allows for the comprehensive quantification of RNA transcripts and for the detection of alternative splicing events, both of which can be influenced by epigenetic marks. Epigenetic effects on gene expression have been discussed above; alternative splicing of pre-mRNA can result from differential DNA methylation where enrichment of methylation promotes exon recognition and produces alternatively spliced exons [112]. Histone acetylation, too, affects splicing events and can generate exon skipping [113]. Given these strengths, RNA sequencing is an ideal technique for identifying genes with expression patterns that vary across the pubertal transition.

Conducting studies in models that lead to alterations in pubertal timing might allow for identification of system components more readily. For example, pharmacological agents such as those discussed above could be used to alter epigenetic marks and alter the timing of puberty followed by the use of RNA sequencing or ChIP-Seq to identify which genes have been affected. The identified genes would be important candidate gene regulatory network members. Epigenetic marks are sensitive to other environmental perturbations, including endocrine disrupting chemicals and diet, and these perturbations could also be used to alter pubertal timing followed by assessment of how the epigenome was affected. Even without environmental manipulation, the C57BL/6 strain of female mice already displays wide variation in timing of puberty, and the epigenomes of extreme early- and lateonset mice could be compared to each other to identify key regulators (fig. 1). 


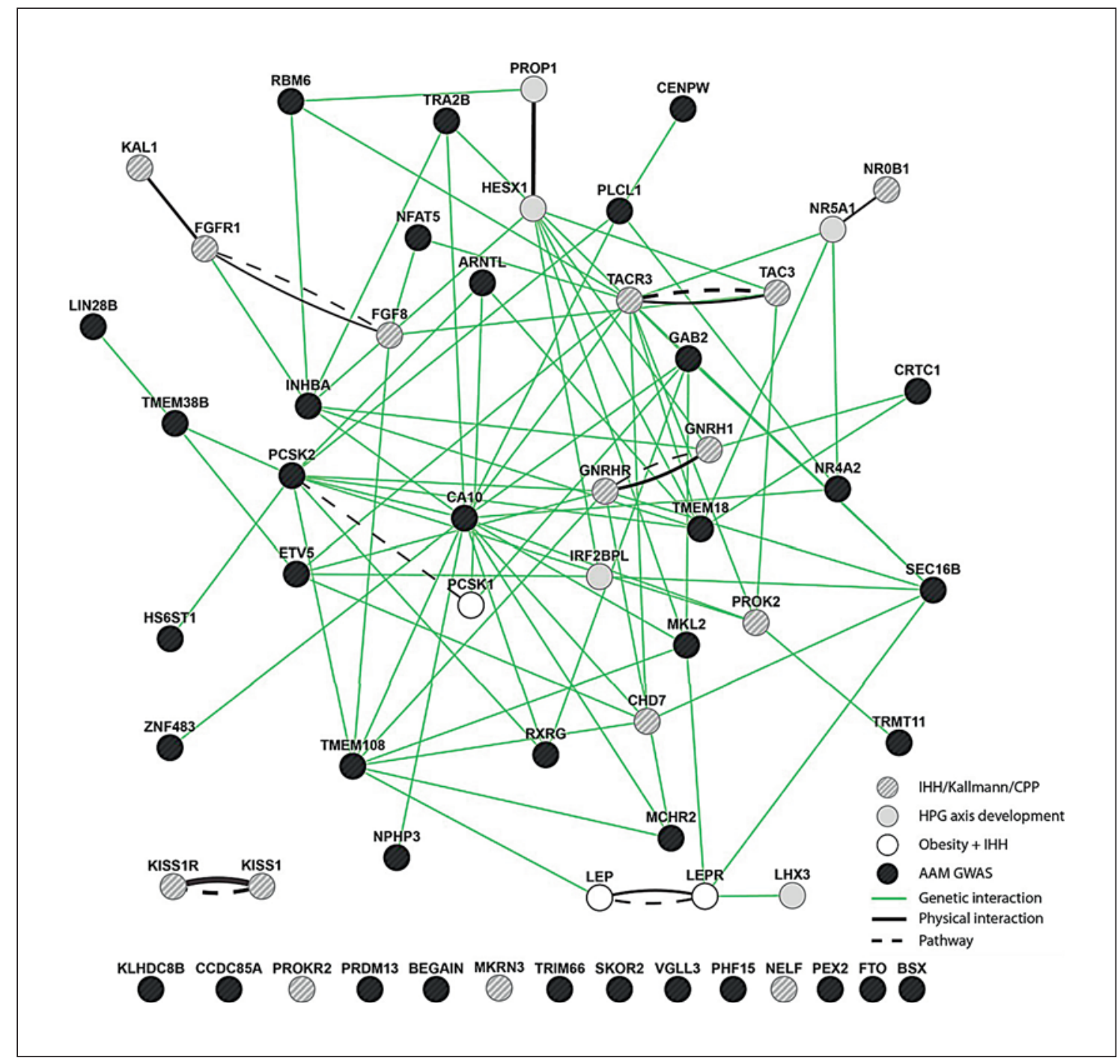

Fig. 4. Gene regulatory network illustrating putative interactions among genes known to cause hypogonadotropic hypogonadism and Lin $28 B$ and other AAM-associated loci. AAM genes from Elks et al. [106] are shown as black circles. Kallmann syndrome (KS; KAL1, FGFR1, PROK2, PROKR2, FGF8, HS6ST1 and CHD7), isolated hypogonadotropic hypogonadism (IHH; KAL1, GNRHR, GNRH1, GPR54/KISS1R, FGFR1, FGF8, PROK2, PROKR2, TAC3, TACR3. HS6ST1, NELF and CHD7) and central precocious puberty (CPP; MKRN3) genes are shown as hatched gray circles. Of note, some genes have been identified as causes of Kallmann syndrome and isolated hypogonadotropic hypogonadism. Essential HPG axis development genes (DAX1/NR0B1, NR5A1, HESX1,

Transgenic models could also be employed to perturb pubertal timing. For example, female mice overexpressing Lin28a have been shown to have delayed puberty [93], and epigenetic techniques could be used to determine which genes are modulated in transgenic versus control
$L H X 3$, and $P R O P 1$ and IRF2BPL/EAP1) are shown as gray circles. Obesity and hypogonadotropic hypogonadism genes (LEP, LEPR and PCSK1) are shown as white circles. Genetic interactions that were previously characterized using a radiation hybrid approach that utilized human, mouse, dog and rat panels are shown as solid green lines [128]. Proteins known to interact physically are connected by solid black lines, and genes known to be found in the same pathway are connected with dashed black lines. The connections were identified using GeneMania using default parameters with the 'equal weighting by network' setting [129]. Thicker lines represent the highest-confidence genetic or physical interactions.

mice. Finally, since the timing of puberty differs between boys and girls, sex-specific differences in the epigenome could be leveraged in the discovery of gene regulatory network components. 
Table 2. Summary of techniques that could be used for the identification of genes and epigenetic mechanisms involved in the regulation of pubertal timing

\begin{tabular}{ll}
\hline Technique & Purpose \\
\hline DNA methylation array & $\begin{array}{l}\text { Measure DNA methylation levels at CpG sites and identify areas with methylation } \\
\text { profiles that favor more (generally less methylation) or less transcription }\end{array}$ \\
\hline DNase I hypersensitive site sequencing & $\begin{array}{l}\text { Genome-wide identification of nucleosome-depleted regions (open chromatin, which } \\
\text { indicates areas with conformation that favors transcription and/or binding of regulatory } \\
\text { elements) }\end{array}$ \\
\hline $\begin{array}{ll}\text { ChIP-Seq } \\
\text { Assay for transposase-accessible } \\
\text { chromatin using sequencing }\end{array}$ & $\begin{array}{l}\text { Genome-wide characterization of sites where DNA-binding proteins and particular } \\
\text { immunoprecipitation, can identify areas that are more or less poised for transcription }\end{array}$ \\
$\begin{array}{l}\text { Genome-wide identification of both nucleosome occupancy profile and nucleosome- } \\
\text { depleted regions. A mechanism that fragments the genome at accessible regions and } \\
\text { simultaneously generates a sequencing library, allowing for identification of areas with } \\
\text { open chromatin with much lower quantities of DNA than needed for DNase sequencing } \\
\text { or ChIP-Seq, facilitating studies with a small number of cells }\end{array}$ \\
$\begin{array}{l}\text { Next-generation sequencing of } \\
\text { transcripts }\end{array}$ \\
$\begin{array}{l}\text { Transcription activator-like } \\
\text { effector-mediated epigenetic } \\
\text { modification }\end{array}$ & $\begin{array}{l}\text { Technique that allows for targeted removal (or addition) of epigenetic marks by } \\
\text { delivering epigenetic modifiers to specific genomic loci, allowing for assessment of the } \\
\text { function of the particular mark. To date, this approach has been used to remove } \\
\text { methylation at CpG sites as well as methylation at lysine } 3 \text { on histone H3 }\end{array}$ \\
\hline
\end{tabular}

\section{Dissecting Epigenetic Changes across Tissues and \\ Development}

Central to understanding the interplay between genes and environment is to know where (what cell type) and when (what development stage) to look. A host of genes have been documented that have defined roles in modulating pubertal timing and that show dynamic expression over the pubertal transition, including Lin $28 a / b$, Kiss 1 and Mkmr3, among others [22, 94, 114]. Even when the genes of interest are known, it is often unclear how far in advance of the pubertal transition one should look for differential patterns. Some epigenetic marks are dynamic and lead to dynamic changes in gene expression. Other marks are persistent, placed at embryogenesis until they are functionally relevant at a certain point in time, thus representing a programmed state [115, 116]. A persistent pattern would dictate that individuals with different pubertal timing profiles (early onset versus late onset) would have different epigenetic marks from embryogenesis until (and perhaps after) the onset of puberty.

The range of tissues and developmental windows that could play a role in regulating the timing of puberty also makes it difficult to predict which transcription factors are most relevant. Thus, it is important to consider techniques that might allow for discovery even without more precise knowledge. Several methods exist to look globally for regulatory regions, including performing ChIPSeq using antibodies to CTCF and the ring-shaped cohesin complex, both of which play critical roles in controlling the epigenome [104], or to HPTMs such as H3K27Ac or H3K4me2 (fig. 2). The gold standard for mapping open chromatin is sensitivity to the enzyme DNase I $[108,117,118]$. DNAse I hypersensitivity profiles from multiple cell types of different lineages and developmental stages have revealed that many DNAse I hypersensitivities are propagated during differentiation [117]. Translating these findings to puberty research is encouraging and suggests that many insights into precise locations of epigenetic regulation might be gained without choosing exactly the right time point to study [119].

Since tissue choice in human studies is limited to blood and peripheral tissues, or posthumous dissections, puberty research has relied heavily on animal models for advances in the field. However, even in ani- 
mal models, performing analyses on pituitary samples or individual hypothalamic nuclei has been challenging due to small sample sizes. However, recent advances in obtaining signatures of open chromatin from small samples with assay for transposase-accessible chromatin using sequencing have just been reported, which may open up new opportunities for puberty research [120]. Furthermore, we may soon be able to test the importance of particular epigenetic marks in regulating the timing of puberty. Scalable genome-editing techniques such as the transcription activator-like effector nuclease have just been harnessed to make site-specific epigenetic changes. For example, $\mathrm{CpG}$ methylation can be erased at specific loci using transcription activatorlike effector to recruit the demethylating enzyme TET1 to specific loci, allowing for erasure and then investigation of the functional significance of particular $\mathrm{CpG}$ methylation marks on the phenotype of interest [121]. Demethylation of enhancer-associated HPTMs has been achieved by transcription activator-like effector nuclease recruiting LSD1 to specific chromatin loci [122]. Using these and other technologies (table 2), investigators will be able to test whether altering a specific epigenetic mark alters the timing of puberty and whether that gene should be included in a puberty-related gene regulatory network.

\section{Conclusion}

Recent work by several groups has ushered the regulation of the HPG axis and of the timing of puberty into the epigenetic era. In total, the studies linking epigenetic control to pubertal timing provide consistent evidence that the initiation of puberty requires a lifting of repression, mediated by repressive epigenetic mechanisms. Global changes in specific epigenetic factors, such as the PRC2 complex [43], appear to be key players in the regulation of the onset of puberty. Further work in this area will enhance our understanding of the factors and gene regulatory networks that control the HPG axis and that underlie the wide variation in the timing of puberty observed among humans. The identification of these new gene regulatory networks is important to our understanding of puberty but may also help us understand further how the timing of puberty affects later-life health outcomes. This prediction will hold true if components of the newly identified networks overlap, at least in some cases, with genes or pathways that are involved in the pathogenesis of the medical outcomes (e.g. cardiovascular disease, diabetes, cancer) associated with age of onset of puberty.

\section{Acknowledgments}

M.D.W. was funded by NSERC and Canada Research Chair in Comparative Genomics.

\section{References}

1 Palmert MR, Dunkel L: Clinical practice. Delayed puberty. N Engl J Med 2012;366:443-453.

2 Hunter DJ, Spiegelman D, Adami HO, van den Brandt PA, Folsom AR, Goldbohm RA, Graham S, Howe GR, Kushi LH, Marshall JR, Miller AB, Speizer FE, Willett W, Wolk A, Yaun SS: Non-dietary factors as risk factors for breast cancer, and as effect modifiers of the association of fat intake and risk of breast cancer. Cancer Causes Control 1997;8:49-56.

3 Key TJ, Verkasalo PK, Banks E: Epidemiology of breast cancer. Lancet Oncol 2001;2:133140.

4 Velie EM, Nechuta S, Osuch JR: Lifetime reproductive and anthropometric risk factors for breast cancer in postmenopausal women. Breast Dis 2005;24:17-35.

5 Lakshman R, Forouhi NG, Sharp SJ, Luben R, Bingham SA, Khaw KT, Wareham NJ, Ong KK: Early age at menarche associated with cardiovascular disease and mortality. J Clin Endocrinol Metab 2009;94:4953-4960.
6 Kaltiala-Heino R, Kosunen E, Rimpela M: Pubertal timing, sexual behaviour and self-reported depression in middle adolescence. J Adolesc 2003;26:531-545.

7 Kaltiala-Heino R, Rimpela M, Rissanen A, Rantanen P: Early puberty and early sexual activity are associated with bulimic-type eating pathology in middle adolescence. J Adolesc Health 2001;28:346-352.

8 Golub MS, Collman GW, Foster PM, Kimmel CA, Rajpert-De Meyts E, Reiter EO, Sharpe RM, Skakkebaek NE, Toppari J: Public health implications of altered puberty timing. Pediatrics 2008;121(suppl 3):S218-S230.

9 Elks CE, Ong KK, Scott RA, van der Schouw YT, Brand JS, Wark PA, Amiano P, Balkau B, Barricarte A, Boeing H, Fonseca-Nunes A, Franks PW, Grioni S, Halkjaer J, Kaaks R, Key TJ, Khaw KT, Mattiello A, Nilsson PM, Overvad K, Palli D, Quiros JR, Rinaldi S, Rolandsson O, Romieu I, Sacerdote C, Sanchez MJ, Spijkerman AM, Tjonneland A, Tormo MJ,
Tumino R, van der ADL, Forouhi NG, Sharp SJ, Langenberg C, Riboli E, Wareham NJ; InterAct Consortium: Age at menarche and type 2 diabetes risk: the EPIC-InterAct study. Diabetes Care 2013;36:3526-3534.

10 Jacobsen BK, Heuch I, Kvale G: Association of low age at menarche with increased allcause mortality: a 37-year follow-up of 61,319 Norwegian women. Am J Epidemiol 2007; 166:1431-1437.

11 Cooper GS, Ephross SA, Weinberg CR, Baird DD, Whelan EA, Sandler DP: Menstrual and reproductive risk factors for ischemic heart disease. Epidemiology 1999;10:255-259.

12 Naves M, Diaz-Lopez JB, Gomez C, Rodriguez-Rebollar A, Cannata-Andia JB: Determinants of incidence of osteoporotic fractures in the female Spanish population older than 50. Osteoporos Int 2005;16:2013-2017.

13 Eastell R: Role of oestrogen in the regulation of bone turnover at the menarche. J Endocrinol 2005; 185:223-234. 
14 Sawyer SM, Afifi RA, Bearinger LH, Blakemore SJ, Dick B, Ezeh AC, Patton GC: Adolescence: a foundation for future health. Lancet 2012;379:1630-1640.

15 Ong KK, Elks CE, Wills AK, Wong A, Wareham NJ, Loos RJ, Kuh D, Hardy R: Associations between the pubertal timing-related variant in LIN28B and BMI vary across the life course. J Clin Endocrinol Metab 2011; 96:E125-E129.

16 Perry JR, Stolk L, Franceschini N, Lunetta KL, Zhai G, McArdle PF, Smith AV, Aspelund T, Bandinelli S, Boerwinkle E, Cherkas L, Eiriksdottir G, Estrada K, Ferrucci L, Folsom AR, Garcia M, Gudnason V, Hofman A, Karasik D, Kiel DP, Launer LJ, van Meurs J, Nalls MA, Rivadeneira F, Shuldiner AR, Singleton A, Soranzo N, Tanaka T, Visser JA, Weedon MN, Wilson SG, Zhuang V, et al: Meta-analysis of genome-wide association data identifies two loci influencing age at menarche. Nat Genet 2009;41:648-650.

17 Elks CE, Perry JR, Sulem P, Chasman DI, Franceschini N, He C, Lunetta KL, Visser JA, Byrne EM, Cousminer DL, Gudbjartsson DF, Esko T, Feenstra B, Hottenga JJ, Koller DL, Kutalik Z, Lin P, Mangino M, Marongiu M, McArdle PF, Smith AV, Stolk L, van Wingerden SH, Zhao JH, Albrecht E, Corre T, Ingelsson E, Hayward C, Magnusson PK, Smith EN, Ulivi S, Warrington NM, Zgaga L, et al: Thirty new loci for age at menarche identified by a meta-analysis of genome-wide association studies. Nat Genet 2010;42:1077-1085.

18 Sulem P, Gudbjartsson DF, Rafnar T, Holm H, Olafsdottir EJ, Olafsdottir GH, Jonsson T, Alexandersen P, Feenstra B, Boyd HA, Aben KK, Verbeek AL, Roeleveld N, Jonasdottir A, Styrkarsdottir U, Steinthorsdottir V, Karason A, Stacey SN, Gudmundsson J, Jakobsdottir M, Thorleifsson G, Hardarson G, Gulcher J, Kong A, Kiemeney LA, Melbye M, Christiansen C, Tryggvadottir L, Thorsteinsdottir U, Stefansson K: Genome-wide association study identifies sequence variants on $6 \mathrm{q} 21$ associated with age at menarche. Nat Genet 2009; 41:734-738.

19 He C, Kraft P, Chasman DI, Buring JE, Chen C, Hankinson SE, Pare G, Chanock S, Ridker PM, Hunter DJ: A large-scale candidate gene association study of age at menarche and age at natural menopause. Hum Genet 2010;128: 515-527.

20 Gajdos ZK, Henderson KD, Hirschhorn JN, Palmert MR: Genetic determinants of pubertal timing in the general population. Mol Cell Endocrinol 2010;324:21-29.

21 Silveira LF, Latronico AC: Approach to the patient with hypogonadotropic hypogonadism. J Clin Endocrinol Metab 2013;98:17811788 .
22 Abreu AP, Dauber A, Macedo DB, Noel SD, Brito VN, Gill JC, Cukier P, Thompson IR, Navarro VM, Gagliardi PC, Rodrigues T, Kochi C, Longui CA, Beckers D, de Zegher F, Montenegro LR, Mendonca BB, Carroll RS, Hirschhorn JN, Latronico AC, Kaiser UB: Central precocious puberty caused by mutations in the imprinted gene MKRN3. N Engl J Med 2013;368:2467-2475.

23 Eaves L, Silberg J, Foley D, Bulik C, Maes H, Erkanli A, Angold A, Costello EJ, Worthman C: Genetic and environmental influences on the relative timing of pubertal change. Twin Res 2004; 7:471-481.

24 Rzeczkowska PA, Alm C, Ramkumar JM, Palmert MR: Do epigenetic mechanisms regulate the timing of puberty? Initial evidence from studies in female mice. Canadian Pediatric Endocrine Group Scientific Meeting, Toronto, 2011, p 34.

25 Nathan BM, Hodges CA, Supelak PJ, Burrage LC, Nadeau JH, Palmert MR: A quantitative trait locus on chromosome 6 regulates the onset of puberty in mice. Endocrinology 2006; 147:5132-5138.

26 Chan JL, Mantzoros CS: Role of leptin in energy-deprivation states: normal human physiology and clinical implications for hypothalamic amenorrhoea and anorexia nervosa. Lancet 2005;366:74-85.

27 Dicken CL, Israel DD, Davis JB, Sun Y, Shu J, Hardin J, Neal-Perry G: Peripubertal vitamin $D(3)$ deficiency delays puberty and disrupts the estrous cycle in adult female mice. Biol Reprod 2012;87:51.

28 Aksglaede L, Juul A, Olsen LW, Sorensen TI: Age at puberty and the emerging obesity epidemic. PLoS One 2009;4:e8450.

29 Kinsey-Jones JS, Li XF, Knox AM, Lin YS, Milligan SR, Lightman SL, O’Byrne KT: Corticotrophin-releasing factor alters the timing of puberty in the female rat. J Neuroendocrinol 2010;22:102-109.

30 Bourguignon JP, Franssen D, Gerard A, Janssen S, Pinson A, Naveau E, Parent AS: Early neuroendocrine disruption in hypothalamus and hippocampus: developmental effects including female sexual maturation and implications for endocrine disrupting chemical screening. J Neuroendocrinol 2013;25:10791087.

31 Iwasa T, Matsuzaki T, Murakami M, Fujisawa S, Kinouchi R, Gereltsetseg G, Kuwahara A, Yasui T, Irahara M: Effects of intrauterine undernutrition on hypothalamic Kiss1 expression and the timing of puberty in female rats. J Physiol 2010;588:821-829.

32 Ojeda SR, Dubay C, Lomniczi A, Kaidar G, Matagne V, Sandau US, Dissen GA: Gene networks and the neuroendocrine regulation of puberty. Mol Cell Endocrinol 2010;324:3-11.

33 Bird A: DNA methylation patterns and epigenetic memory. Genes Dev 2002;16:6-21.

34 Pozo J, Argente J: Delayed puberty in chronic illness. Best Pract Res Clin Endocrinol Metab 2002;16:73-90.
35 Boyar RM, Katz J, Finkelstein JW, Kapen S, Weiner H, Weitzman ED, Hellman L: Anorexia nervosa. Immaturity of the 24-hour luteinizing hormone secretory pattern. $\mathrm{N}$ Engl J Med 1974;291:861-865.

36 Pitteloud N, Durrani S, Raivio T, Sykiotis GP. Complex genetics in idiopathic hypogonadotropic hypogonadism. Front Horm Res 2010; 39:142-153.

37 Roth CL, Sathyanarayana S: Mechanisms affecting neuroendocrine and epigenetic regulation of body weight and onset of puberty: potential implications in the child born small for gestational age (SGA). Rev Endocr Metab Disord 2012;13:129-140.

38 Roth CL, Mastronardi C, Lomniczi A, Wright H, Cabrera R, Mungenast AE, Heger S, Jung H, Dubay C, Ojeda SR: Expression of a tumorrelated gene network increases in the mammalian hypothalamus at the time of female puberty. Endocrinology 2007;148:5147-5161.

39 Cameron N, Del Corpo A, Diorio J, McAllister K, Sharma S, Meaney MJ: Maternal programming of sexual behavior and hypothalamic-pituitary-gonadal function in the female rat. PLoS One 2008;3:e2210.

40 Ojeda SR, Lomniczi A, Sandau U, Matagne V: New concepts on the control of the onset of puberty. Endocr Dev 2010;17:44-51.

41 Kurian JR, Terasawa E: Epigenetic control of gonadotropin releasing hormone neurons. Front Endocrinol (Lausanne) 2013;4:61.

42 Gill JC, Kwong C, Clark E, Carroll RS, Shi YG, Kaiser UB: A role for the histone demethylase LSD1 in controlling the timing of pubertal onset. Endocrine Society Meeting, Houston, 2012, vol 33, pp OR12-OR13.

43 Lomniczi A, Loche A, Castellano JM, Ronnekleiv OK, Bosch M, Kaidar G, Knoll JG, Wright H, Pfeifer GP, Ojeda SR: Epigenetic control of female puberty. Nat Neurosci 2013; 16:281-289.

44 Lister R, Pelizzola M, Dowen RH, Hawkins RD, Hon G, Tonti-Filippini J, Nery JR, Lee L, Ye Z, Ngo QM, Edsall L, Antosiewicz-Bourget J, Stewart R, Ruotti V, Millar AH, Thomson JA, Ren B, Ecker JR: Human DNA methylomes at base resolution show widespread epigenomic differences. Nature 2009;462: 315-322.

45 Lawson HA, Cheverud JM, Wolf JB: Genomic imprinting and parent-of-origin effects on complex traits. Nat Rev Genet 2013;14:609617.

46 Jones PA: Functions of DNA methylation: islands, start sites, gene bodies and beyond. Nat Rev Genet 2012;13:484-492.

47 Hellman A, Chess A: Gene body-specific methylation on the active $\mathrm{X}$ chromosome. Science 2007;315:1141-1143. 
48 Maunakea AK, Nagarajan RP, Bilenky M, Ballinger TJ, D'Souza C, Fouse SD, Johnson BE, Hong C, Nielsen C, Zhao Y, Turecki G, Delaney A, Varhol R, Thiessen N, Shchors K, Heine VM, Rowitch DH, Xing X, Fiore C, Schillebeeckx M, Jones SJ, Haussler D, Marra MA, Hirst M, Wang T, Costello JF: Conserved role of intragenic DNA methylation in regulating alternative promoters. Nature 2010; 466:253-257.

49 Serandour AA, Avner S, Percevault F, Demay F, Bizot M, Lucchetti-Miganeh C, BarloyHubler F, Brown M, Lupien M, Metivier R, Salbert G, Eeckhoute J: Epigenetic switch involved in activation of pioneer factor FOXA1dependent enhancers. Genome Res 2011;21: 555-565.

50 Stadler MB, Murr R, Burger L, Ivanek R, Lienert F, Scholer A, van Nimwegen E, Wirbelauer C, Oakeley EJ, Gaidatzis D, Tiwari VK, Schubeler D: DNA-binding factors shape the mouse methylome at distal regulatory regions. Nature 2011;480:490-495.

51 Gutierrez-Arcelus M, Lappalainen T, Montgomery SB, Buil A, Ongen $\mathrm{H}$, Yurovsky A, Bryois J, Giger T, Romano L, Planchon A, Falconnet E, Bielser D, Gagnebin M, Padioleau I, Borel C, Letourneau A, Makrythanasis P, Guipponi M, Gehrig C, Antonarakis SE, Dermitzakis ET: Passive and active DNA methylation and the interplay with genetic variation in gene regulation. Elife 2013;2:e00523.

52 Jaenisch R, Bird A: Epigenetic regulation of gene expression: how the genome integrates intrinsic and environmental signals. Nat Genet 2003;33(suppl):245-254.

53 Kohli RM, Zhang Y: TET enzymes, TDG and the dynamics of DNA demethylation. Nature 2013;502:472-479.

54 Mellen M, Ayata P, Dewell S, Kriaucionis S, Heintz N: MeCP2 binds to $5 \mathrm{hmC}$ enriched within active genes and accessible chromatin in the nervous system. Cell 2012;151:1417-1430.

55 Munzel M, Globisch D, Bruckl T, Wagner M, Welzmiller V, Michalakis S, Muller M, Biel M, Carell T: Quantification of the sixth DNA base hydroxymethylcytosine in the brain. Angew Chem Int Ed Engl 2010;49:5375-5377.

56 ENCODE Project Consortium, Bernstein BE, Birney E, Dunham I, Green ED, Gunter C, Snyder M: An integrated encyclopedia of DNA elements in the human genome. Nature 2012;489:57-74.

57 Bernstein BE, Stamatoyannopoulos JA, Costello JF, Ren B, Milosavljevic A, Meissner A, Kellis M, Marra MA, Beaudet AL, Ecker JR, Farnham PJ, Hirst M, Lander ES, Mikkelsen TS, Thomson JA: The NIH Roadmap Epigenomics Mapping Consortium. Nat Biotechnol 2010;28:1045-1048.

58 Hoffman MM, Ernst J, Wilder SP, Kundaje A, Harris RS, Libbrecht M, Giardine B, Ellenbogen PM, Bilmes JA, Birney E, Hardison RC, Dunham I, Kellis M, Noble WS: Integrative annotation of chromatin elements from ENCODE data. Nucleic Acids Res 2013;41:827841.
59 Ernst J, Kheradpour P, Mikkelsen TS, Shoresh N, Ward LD, Epstein CB, Zhang X, Wang L, Issner R, Coyne M, Ku M, Durham T, Kellis $\mathrm{M}$, Bernstein BE: Mapping and analysis of chromatin state dynamics in nine human cell types. Nature 2011;473:43-49.

60 Strahl BD, Allis CD: The language of covalent histone modifications. Nature 2000;403:4145.

61 Jenuwein T, Allis CD: Translating the histone code. Science 2001;293:1074-1080.

62 Clayton AL, Hazzalin CA, Mahadevan LC: Enhanced histone acetylation and transcription: a dynamic perspective. Mol Cell 2006;23: 289-296.

63 Hong L, Schroth GP, Matthews HR, Yau P, Bradbury EM: Studies of the DNA binding properties of histone $\mathrm{H} 4$ amino terminus. Thermal denaturation studies reveal that acetylation markedly reduces the binding constant of the $\mathrm{H}_{4}$ 'tail' to DNA. J Biol Chem 1993;268:305-314.

64 Di Croce L, Helin K: Transcriptional regulation by Polycomb group proteins. Nat Struct Mol Biol 2013;20:1147-1155.

65 Bernstein BE, Mikkelsen TS, Xie X, Kamal M, Huebert DJ, Cuff J, Fry B, Meissner A, Wernig M, Plath K, Jaenisch R, Wagschal A, Feil R, Schreiber SL, Lander ES: A bivalent chromatin structure marks key developmental genes in embryonic stem cells. Cell 2006;125:315326.

66 Villeneuve LM, Reddy MA, Lanting LL, Wang M, Meng L, Natarajan R: Epigenetic histone $\mathrm{H} 3$ lysine 9 methylation in metabolic memory and inflammatory phenotype of vascular smooth muscle cells in diabetes. Proc Natl Acad Sci USA 2008;105:9047-9052.

67 Ostuni R, Piccolo V, Barozzi I, Polletti S, Termanini A, Bonifacio S, Curina A, Prosperini E, Ghisletti S, Natoli G: Latent enhancers activated by stimulation in differentiated cells. Cell 2013;152:157-171.

68 Burdge GC, Lillycrop KA: Nutrition, epigenetics, and developmental plasticity: implications for understanding human disease. Annu Rev Nutr 2010;30:315-339.

69 Hockly E, Richon VM, Woodman B, Smith DL, Zhou X, Rosa E, Sathasivam K, GhaziNoori S, Mahal A, Lowden PA, Steffan JS, Marsh JL, Thompson LM, Lewis CM, Marks PA, Bates GP: Suberoylanilide hydroxamic acid, a histone deacetylase inhibitor, ameliorates motor deficits in a mouse model of Huntington's disease. Proc Natl Acad Sci USA 2003;100:2041-2046.

70 Kelly WK, O’Connor OA, Krug LM, Chiao JH, Heaney M, Curley T, MacGregore-Cortelli B, Tong W, Secrist JP, Schwartz L, Richardson S, Chu E, Olgac S, Marks PA, Scher H, Richon VM: Phase I study of an oral histone deacetylase inhibitor, suberoylanilide hydroxamic acid, in patients with advanced cancer. J Clin Oncol 2005;23:3923-3931.
71 Palmieri D, Lockman PR, Thomas FC, Hua E, Herring J, Hargrave E, Johnson M, Flores N, Qian Y, Vega-Valle E, Taskar KS, Rudraraju V, Mittapalli RK, Gaasch JA, Bohn KA, Thorsheim HR, Liewehr DJ, Davis S, Reilly JF, Walker R, Bronder JL, Feigenbaum L, Steinberg SM, Camphausen K, Meltzer PS, Richon VM, Smith QR, Steeg PS: Vorinostat inhibits brain metastatic colonization in a model of triple-negative breast cancer and induces DNA double-strand breaks. Clin Cancer Res 2009;15:6148-6157.

72 Kilgore M, Miller CA, Fass DM, Hennig KM, Haggarty SJ, Sweatt JD, Rumbaugh G: Inhibitors of class 1 histone deacetylases reverse contextual memory deficits in a mouse model of Alzheimer's disease. Neuropsychopharmacology 2010;35:870-880.

73 Weaver IC, Cervoni N, Champagne FA, D’Alessio AC, Sharma S, Seckl JR, Dymov S, Szyf M, Meaney MJ: Epigenetic programming by maternal behavior. Nat Neurosci 2004;7: 847-854.

74 Milutinovic S, D’Alessio AC, Detich N, Szyf M: Valproate induces widespread epigenetic reprogramming which involves demethylation of specific genes. Carcinogenesis 2007; 28:560-571.

75 Cervoni N, Szyf M: Demethylase activity is directed by histone acetylation. J Biol Chem 2001;276:40778-40787.

76 Chiang PK, Gordon RK, Tal J, Zeng GC, Doctor BP, Pardhasaradhi K, McCann PP: S-adenosylmethionine and methylation. FASEB J 1996;10:471-480.

77 Semaan SJ, Kauffman AS: Emerging concepts on the epigenetic and transcriptional regulation of the Kiss1 gene. Int J Dev Neurosci 2013;31:452-462.

78 Kurian JR, Keen KL, Terasawa E: Epigenetic changes coincide with in vitro primate $\mathrm{GnRH}$ neuronal maturation. Endocrinology 2010; 151:5359-5368.

79 Iyer AK, Brayman MJ, Mellon PL: Dynamic chromatin modifications control GnRH gene expression during neuronal differentiation and protein kinase $\mathrm{C}$ signal transduction. $\mathrm{Mol}$ Endocrinol 2011;25:460-473.

80 Schwarz JM, Nugent BM, McCarthy MM: Developmental and hormone-induced epigenetic changes to estrogen and progesterone receptor genes in brain are dynamic across the life span. Endocrinology 2010;151:4871-4881.

81 Semaan SJ, Dhamija S, Kim J, Ku EC, Kauffman AS: Assessment of epigenetic contributions to sexually dimorphic Kiss1 expression in the anteroventral periventricular nucleus of mice. Endocrinology 2012;153:1875-1886.

82 Tomikawa J, Uenoyama Y, Ozawa M, Fukanuma T, Takase K, Goto T, Abe H, Ieda N, Minabe S, Deura C, Inoue N, Sanbo M, Tomita K, Hirabayashi $M$, Tanaka S, Imamura T, Okamura H, Maeda K, Tsukamura H: Epigenetic regulation of Kiss1 gene expression mediating estrogen-positive feedback action in the mouse brain. Proc Natl Acad Sci USA 2012;109:E1294-E1301. 
83 Lomniczi A, Wright H, Castellano JM, Sonmez K, Ojeda SR: A system biology approach to identify regulatory pathways underlying the neuroendocrine control of female puberty in rats and nonhuman primates. Horm Behav 2013;64:175-186.

84 Ojeda SR, Lomniczi A, Loche A, Matagne V, Kaidar G, Sandau US, Dissen GA: The transcriptional control of female puberty. Brain Res 2010;1364:164-174.

85 Navarro VM, Gottsch ML, Wu M, GarciaGaliano D, Hobbs SJ, Bosch MA, Pinilla L, Clifton DK, Dearth A, Ronnekleiv OK, Braun RE, Palmiter RD, Tena-Sempere M, Alreja M, Steiner RA: Regulation of NKB pathways and their roles in the control of Kiss1 neurons in the arcuate nucleus of the male mouse. Endocrinology 2011;152:4265-4275.

86 Goodman RL, Hileman SM, Nestor CC, Porter KL, Connors JM, Hardy SL, Millar RP, Cernea M, Coolen LM, Lehman MN: Kisspeptin, neurokinin $B$, and dynorphin act in the arcuate nucleus to control activity of the $\mathrm{GnRH}$ pulse generator in ewes. Endocrinology 2013;154:4259-4269.

87 Tena-Sempere M: Deciphering puberty: novel partners, novel mechanisms. Eur J Endocrinol 2012;167:733-747.

88 Mercer TR, Mattick JS: Structure and function of long noncoding RNAs in epigenetic regulation. Nat Struct Mol Biol 2013;20:300307.

89 Rinn JL, Chang HY: Genome regulation by long noncoding RNAs. Annu Rev Biochem 2012;81:145-166.

90 Guttman M, Donaghey J, Carey BW, Garber M, Grenier JK, Munson G, Young G, Lucas AB, Ach R, Bruhn L, Yang X, Amit I, Meissner A, Regev A, Rinn JL, Root DE, Lander ES: lincRNAs act in the circuitry controlling pluripotency and differentiation. Nature 2011; 477:295-300.

$91 \mathrm{Ng} \mathrm{SY}$, Johnson R, Stanton LW: Human long non-coding RNAs promote pluripotency and neuronal differentiation by association with chromatin modifiers and transcription factors. EMBO J 2012;31:522-533.

92 Moss EG, Lee RC, Ambros V: The cold shock domain protein LIN-28 controls developmental timing in C. elegans and is regulated by the lin-4 RNA. Cell 1997;88:637-646.

93 Zhu H, Shah S, Shyh-Chang N, Shinoda G, Einhorn WS, Viswanathan SR, Takeuchi A, Grasemann C, Rinn JL, Lopez MF, Hirschhorn JN, Palmert MR, Daley GQ: Lin28a transgenic mice manifest size and puberty phenotypes identified in human genetic association studies. Nat Genet 2010;42:626-630.

94 Grieco A, Rzeczkowska P, Alm C, Palmert MR: Investigation of peripubertal expression of Lin28a and Lin28b in C57BL/6 female mice. Mol Cell Endocrinol 2013;365:241248.
95 Sangiao-Alvarellos S, Manfredi-Lozano M, Ruiz-Pino F, Navarro VM, Sanchez-Garrido MA, Leon S, Dieguez C, Cordido F, Matagne V, Dissen GA, Ojeda SR, Pinilla L, Tena-Sempere M: Changes in hypothalamic expression of the Lin28/let-7 system and related microRNAs during postnatal maturation and after experimental manipulations of puberty. Endocrinology 2013;154:942955.

96 Zinzen RP, Girardot C, Gagneur J, Braun M, Furlong EE: Combinatorial binding predicts spatio-temporal cis-regulatory activity. $\mathrm{Na}$ ture 2009;462:65-70.

97 Gerstein MB, Kundaje A, Hariharan M, Landt SG, Yan KK, Cheng C, Mu XJ, Khurana E, Rozowsky J, Alexander R, Min R, Alves P, Abyzov A, Addleman N, Bhardwaj N, Boyle AP, Cayting P, Charos A, Chen DZ Cheng Y, Clarke D, Eastman C, Euskirchen G, Frietze S, Fu Y, Gertz J, Grubert F, Harmanci A, Jain P, Kasowski M, Lacroute P, Leng J, Lian J, Monahan $\mathrm{H}$, O'Geen $\mathrm{H}$, Ouyang Z, Partridge EC, Patacsil D, Pauli F, Raha D, Ramirez L, Reddy TE, Reed B, Shi M, Slifer T, Wang J, Wu L, Yang X, Yip KY, Zilberman-Schapira G, Batzoglou S, Sidow A, Farnham PJ, Myers RM, Weissman SM, Snyder M: Architecture of the human regulatory network derived from ENCODE data. Nature 2012;489:91-100.

98 Hardison RC, Taylor J: Genomic approaches towards finding cis-regulatory modules in animals. Nat Rev Genet 2012;13:469-483.

99 De Moraes DC, Vaisman M, Conceicao FL, Ortiga-Carvalho TM: Pituitary development: a complex, temporal regulated process dependent on specific transcriptional factors. J Endocrinol 2012;215:239-245.

100 Budefeld T, Tobet SA, Majdic G: Steroidogenic factor 1 and the central nervous system. J Neuroendocrinol 2012;24:225-235.

101 Heger S, Mastronardi C, Dissen GA, Lomniczi A, Cabrera R, Roth CL, Jung H, Galimi F, Sippell W, Ojeda SR: Enhanced at puberty 1 (EAP1) is a new transcriptional regulator of the female neuroendocrine reproductive axis. J Clin Invest 2007;117:2145-2154.

102 Spitz F, Furlong EE: Transcription factors: from enhancer binding to developmental control. Nat Rev Genet 2012;13:613-626.

103 Pfeifer D, Kist R, Dewar K, Devon K, Lander ES, Birren B, Korniszewski L, Back E, Scherer G: Campomelic dysplasia translocation breakpoints are scattered over $1 \mathrm{Mb}$ proximal to SOX9: evidence for an extended control region. Am J Hum Genet 1999;65:111124.

104 Merkenschlager M, Odom DT: CTCF and cohesin: linking gene regulatory elements with their targets. Cell 2013;152:12851297.
105 Kieffer-Kwon KR, Tang Z, Mathe E, Qian J, Sung MH, Li G, Resch W, Baek S, Pruett N, Grontved L, Vian L, Nelson S, Zare H, Hakim O, Reyon D, Yamane A, Nakahashi H, Kovalchuk AL, Zou J, Joung JK, Sartorelli V, Wei CL, Ruan X, Hager GL, Ruan Y, Casellas $\mathrm{R}$ : Interactome maps of mouse gene regulatory domains reveal basic principles of transcriptional regulation. Cell 2013;155:15071520.

106 Elks CE, Perry JR, Sulem P, Chasman DI, Franceschini N, He C, Lunetta KL, Visser JA, Byrne EM, Cousminer DL, Gudbjartsson DF, Esko T, Feenstra B, Hottenga JJ, Koller DL, Kutalik Z, Lin P, Mangino M, Marongiu M, McArdle PF, Smith AV, Stolk L, van Wingerden $\mathrm{SH}$, Zhao JH, Albrecht E, Corre $\mathrm{T}$, Ingelsson E, Hayward C, Magnusson PK, Smith EN, Ulivi S, Warrington NM, Zgaga L, et al: Thirty new loci for age at menarche identified by a meta-analysis of genomewide association studies. Nat Genet 2010;42: 1077-1085.

107 Lybaek H, Orstavik KH, Prescott T, Hovland R, Breilid H, Stansberg C, Steen VM, Houge G: An $8.9 \mathrm{Mb} 19 \mathrm{p} 13$ duplication associated with precocious puberty and a sporadic 3.9 $\mathrm{Mb} 2 \mathrm{q} 23.3 \mathrm{q} 24.1$ deletion containing NR4A2 in mentally retarded members of a family with an intrachromosomal 19p-into-19q between-arm insertion. Eur J Hum Genet 2009; 17:904-910

108 Thurman RE, Rynes E, Humbert R, Vierstra J, Maurano MT, Haugen E, Sheffield NC, Stergachis AB, Wang H, Vernot B, Garg K, John S, Sandstrom R, Bates D, Boatman L, Canfield TK, Diegel M, Dunn D, Ebersol AK, Frum T, Giste E, Johnson AK, Johnson EM, Kutyavin T, Lajoie B, Lee BK, Lee K, London D, Lotakis D, Neph S, Neri F, Nguyen ED, Qu H, Reynolds AP, Roach V, Safi A, Sanchez ME, et al: The accessible chromatin landscape of the human genome. Nature 2012;489:75-82.

109 Maurano MT, Humbert R, Rynes E, Thurman RE, Haugen E, Wang H, Reynolds AP, Sandstrom R, Qu H, Brody J, Shafer A, Neri F, Lee K, Kutyavin T, Stehling-Sun S, Johnson AK, Canfield TK, Giste E, Diegel M, Bates D, Hansen RS, Neph S, Sabo PJ, Heimfeld S, Raubitschek A, Ziegler S, Cotsapas C, Sotoodehnia N, Glass I, Sunyaev SR, Kaul R, Stamatoyannopoulos JA: Systematic localization of common disease-associated variation in regulatory DNA. Science 2012;337:11901195.

110 Collins SR, Miller KM, Maas NL, Roguev A, Fillingham J, Chu CS, Schuldiner M, Gebbia M, Recht J, Shales M, Ding H, Xu H, Han J, Ingvarsdottir K, Cheng B, Andrews B, Boone C, Berger SL, Hieter P, Zhang Z, Brown GW, Ingles CJ, Emili A, Allis CD, Toczyski DP, Weissman JS, Greenblatt JF, Krogan NJ: Functional dissection of protein complexes involved in yeast chromosome biology using a genetic interaction map. Nature 2007;446: 806-810. 
111 Lin A, Wang RT, Ahn S, Park CC, Smith DJ: A genome-wide map of human genetic interactions inferred from radiation hybrid genotypes. Genome Res 2010;20:1122-1132.

112 Maunakea AK, Chepelev I, Cui K, Zhao K: Intragenic DNA methylation modulates alternative splicing by recruiting $\mathrm{MeCP} 2$ to promote exon recognition. Cell Res 2013;23: 1256-1269.

113 Zhou HL, Luo G, Wise JA, Lou H: Regulation of alternative splicing by local histone modifications: potential roles for RNAguided mechanisms. Nucleic Acids Res 2014;42:701-713.

114 Clarkson J, Boon WC, Simpson ER, Herbison AE: Postnatal development of an estradiol-kisspeptin positive feedback mechanism implicated in puberty onset. Endocrinology 2009;150:3214-3220.

115 Heijmans BT, Tobi EW, Stein AD, Putter H, Blauw GJ, Susser ES, Slagboom PE, Lumey LH: Persistent epigenetic differences associated with prenatal exposure to famine in humans. Proc Natl Acad Sci USA 2008; 105: 17046-17049.

116 Tang WY, Morey LM, Cheung YY, Birch L, Prins GS, Ho SM: Neonatal exposure to estradiol/bisphenol A alters promoter methylation and expression of Nsbp1 and Hpcal1 genes and transcriptional programs of Dnmt3a/b and Mbd2/4 in the rat prostate gland throughout life. Endocrinology 2011; 153:42-55.

117 Stergachis AB, Neph S, Reynolds A, Humbert R, Miller B, Paige SL, Vernot B, Cheng JB, Thurman RE, Sandstrom R, Haugen E, Heimfeld S, Murry CE, Akey JM, Stamatoyannopoulos JA: Developmental fate and cellular maturity encoded in human regulatory DNA landscapes. Cell 2013;154:888903.
118 Mercer TR, Edwards SL, Clark MB, Neph SJ, Wang H, Stergachis AB, John S, Sandstrom R, Li G, Sandhu KS, Ruan Y, Nielsen LK, Mattick JS, Stamatoyannopoulos JA: DNase I-hypersensitive exons colocalize with promoters and distal regulatory elements. Nat Genet 2013;45:852-859.

119 Sheffield NC, Thurman RE, Song L, Safi A, Stamatoyannopoulos JA, Lenhard B, Crawford GE, Furey TS: Patterns of regulatory activity across diverse human cell types predict tissue identity, transcription factor binding, and long-range interactions. Genome Res 2013;23:777-788

120 Buenrostro JD, Giresi PG, Zaba LC, Chang HY, Greenleaf WJ: Transposition of native chromatin for fast and sensitive epigenomic profiling of open chromatin, DNA-binding proteins and nucleosome position. Nat Methods 2013; 10:1213-1218.

121 Maeder ML, Angstman JF, Richardson ME, Linder SJ, Cascio VM, Tsai SQ, Ho QH, Sander JD, Reyon D, Bernstein BE, Costello JF, Wilkinson MF, Joung JK: Targeted DNA demethylation and activation of endogenous genes using programmable TALETET1 fusion proteins. Nat Biotechnol 2013; 31:1137-1142.

122 Mendenhall EM, Williamson KE, Reyon D, Zou JY, Ram O, Joung JK, Bernstein BE: Locus-specific editing of histone modifications at endogenous enhancers. Nat Biotechnol 2013;31:1133-1136.

123 Caron E, Ciofi P, Prevot V, Bouret SG: Alteration in neonatal nutrition causes perturbations in hypothalamic neural circuits controlling reproductive function. J Neurosci 2012;32:11486-11494.
124 Castellano JM, Bentsen AH, Sanchez-Garrido MA, Ruiz-Pino F, Romero M, GarciaGaliano D, Aguilar E, Pinilla L, Dieguez C, Mikkelsen JD, Tena-Sempere M: Early metabolic programming of puberty onset: impact of changes in postnatal feeding and rearing conditions on the timing of puberty and development of the hypothalamic kisspeptin system. Endocrinology 2011;152: 3396-3408.

125 Fuente-Martin E, Granado M, Garcia-Caceres C, Sanchez-Garrido MA, Frago LM, Tena-Sempere M, Argente J, Chowen JA: Early nutritional changes induce sexually dimorphic long-term effects on body weight gain and the response to sucrose intake in adult rats. Metabolism 2012;61:812-822.

126 Feinberg AP, Irizarry RA: Evolution in health and medicine Sackler colloquium: Stochastic epigenetic variation as a driving force of development, evolutionary adaptation, and disease. Proc Natl Acad Sci USA 2010;107(suppl 1):1757-1764.

127 Petronis A: Epigenetics and twins: three variations on the theme. Trends Genet 2006; 22:347-350.

128 Thomas-Chollier M, Darbo E, Herrmann C, Defrance M, Thieffry D, van Helden J: A complete workflow for the analysis of fullsize ChIP-seq (and similar) data sets using peak-motifs. Nat Protoc 2012;7:1551-1568.

129 Chiang CW, Gajdos ZK, Korn JM, Butler JL, Hackett R, Guiducci C, Nguyen TT, Wilks R, Forrester T, Henderson KD, Le Marchand L, Henderson BE, Haiman CA, Cooper RS, Lyon HN, Zhu X, McKenzie CA, Palmert MR, Hirschhorn JN: The efficacy of detecting variants with small effects on the Affymetrix 6.0 platform using pooled DNA. Hum Genet 2011;130:607-621. 